\title{
Agronomic behaviour of some Cynodon dactylon ecotypes for turfgrass use in the Mediterranean climate
}

\author{
Roberto Viggiani, ${ }^{1}$ Vito Marchione, ${ }^{2}$ Giovanna Potenza, ${ }^{1}$ Donato Castronuovo, ${ }^{1}$ \\ Simonetta Fascetti, ${ }^{1}$ Michele Perniola, ${ }^{1}$ Stella Lovelli, ${ }^{1}$ Vincenzo Candido ${ }^{1}$ \\ 'School of Agricultural, Forest, Food and Environmental Sciences, University of Basilicata, \\ Potenza; ${ }^{2}$ Department of Agricultural and Environmental Science, University Aldo Moro \\ of Bari, Italy
}

\begin{abstract}
In Italy, the expansion of turfgrasses is limited by the lack of suitable species for cultivation in the Mediterranean climate. With this view, Mi.Te.A.Med. (Turfgrass improvement in the Mediterranean climate) research project was developed with the main purpose to find out and agronomically characterise native turfgrass species of Southern and Central Italy and to compare them with some commercial cultivars. During the first step of the research, 11 sites from 6 regions of Southern and Central Italy were identified. In these sites 24 ecotypes of Cynodon dactylon L. (Pers.) were collected and their habitus, phenology plus some biometric parameters have been determined. During the two years of research both botanic and agronomic characterisation of the collected $C$. dactylon ecotypes and their comparison
\end{abstract}

Correspondence: Roberto Viggiani, School of Agricultural, Forest, Food and Environmental Sciences, University of Basilicata, viale dell'Ateneo Lucano 10, 85100 Potenza, Italy.

Tel.: +39.971.205371; Fax: +39.0971.205378.

E-mail: roberto.viggiani@unibas.it

Key words: colour, commercial cultivars, ground cover, native species, warm season grasses, turf quality.

Acknowledgements: this work was carried out under the Mi.Te.A.Med. research Project.

Funding: financial support for this study was provided by the Italian Ministry of Agricultural and Forest Policies. The authors thank Mr. Paolo Putignano and Mr. Cosimo Danzi for their valuable help in conducting the experimental trials and in collecting agronomic data.

Conference presentation: Meeting on Environmental Sustainability and Food Security, Potenza, Italy, 2014.

Received for publication: 14 October 2014.

Revision received: 29 November 2014.

Accepted for publication: 1 December 2014.

CC Copyright R. Viggiani et al., 2015

Licensee PAGEPress, Italy

Italian Journal of Agronomy 2015; $10: 622$

doi:10.4081/ija.2015.622

This article is distributed under the terms of the Creative Commons Attribution Noncommercial License (by-nc 3.0) which permits any noncommercial use, distribution, and reproduction in any medium, provided the original author(s) and source are credited. with 3 commercial cultivars (Panama, Transcontinental and Yukon) was carried out. In the first year the colour loss interval was assessed. In the second year, colour index was measured by an electronic colorimeter, weekly growth rate was measured by a turfmeter, turf quality and ground cover percentage were assessed by visual estimate. Some native accessions showed behaviour similar to commercial cultivars while an ecotype from the Abruzzo region showed better results compared to the commercial cultivars for several quality indices.

\section{Introduction}

In the last few year, Italy witnessed an increase of green areas for recreational, technical and sport purposes, which raised the attention of the turfgrass industry on quantitative and qualitative aspects of turfgrasses.

On one hand, this increased interest stimulated an extensive research activity mostly aimed at assessing the adaptation and the aesthetic and functional features of a wide range of cool season grasses (Veronesi et al., 1991b, 1992, 1997; Volterrani et al., 1996, 1997; Davolio et al., 2000; de Bruijn, 2010).

In Italy, the most used species for turfgrass are cool season grasses, which are not always suitable for the climatic condition of Central and Southern Italy, characterised by hot and dry summer. This has led to poor turfgrass performance, low stand persistence, frequent need for stand re-establishment, unsustainable use of irrigation water, all producing unjustified financial and environmental costs (van Wijk, 1993; McCoy and McCoy, 2005; McCoy et al., 2007).

The outstanding tolerance to high temperatures and soil salinity (Malcolm and Smith, 1971; Beard, 1973; Peacock et al., 2004), the resistance to water stress (Volterrani et al., 1996; Cereti, 2004; Marchione, 2004; Huang, 2008; Marchione, 2012) and the excellent recovery rate from biotic and abiotic stress (Croce et al., 2001; Turgeon, 2004) make warm season turfgrasses more adapted to Mediterranean climatic conditions and suitable to increase turf areas in central and Southern Italy (Severmutlu et al., 2011).

The majority of the commercially available turfgrasses used in Italy, are of foreign origin (USA and Australia) (Veronesi and Falcinelli, 1988; Veronesi et al., 1991a). Therefore, a great threat can be the use of this alien plant material into natural ecosystems (Potenza et al., 2012).

The use of native warm-season grasses would be preferred due to their reduced threat to native ecosystems and their greater resistance to high temperature and water deficit stress (Kenna et al., 2008; Erdogan et al., 2011). Native ecotypes represent an important source of genetic variability that can be used to support specific plant breeding programmes. Germplasm of turf ecotypes selected from the areas of potential utilisation or similar environments is much more likely to 
be successful for obtaining new turf cultivars (Romani et al., 2004).

Among warm season grasses, Bermudagrass [Cynodon dactylon L. (Pers.) var. dactylon] is the most used worldwide fur turf purposes.

Until now, the research on Bermudagrass breeding programs in Italy has been scarce (Veronesi and Falcinelli, 1988; Veronesi et al., 1991b; Volterrani et al., 1996; Romani et al., 2002; Marchione, 2004; Romani et al., 2004; De Luca et al., 2008; Potenza et al., 2014) and all the cultivars available on the market are of foreign origin.

There are 9 species and 10 varieties of Cynodon in the world that are widely distributed, genetically diverse, and generally considered leading reclamation pioneer species. Bermudagrass plants thrive in overgrazed pastures and other disturbed and degraded sites (Chapman, 1996).

C. dactylon var. dactylon (common Bermudagrass) is the most important Cynodon species and is geographically widely distributed between latitudes of $45^{\circ} \mathrm{N}$ and $45^{\circ} \mathrm{S}$ (Anderson et al., 1993), penetrating to approximately $53^{\circ} \mathrm{N}$ in Europe (Harlan and de Wet, 1969).

Cynodon spp. L.C. Rich. is frequently used in the transition zone where it can provide an excellent surface for golf course fairways and athletic fields. However, these species have a tendency to be injured or killed by low temperatures in the transition zone (Munshaw et al., 2006; Anderson et al., 2007; Esmaili and Salehi, 2012).

Moreover, native ecotypes can be affected by bermudagrass white leaf (BGWL) disease that is associated with a phytoplasma infection (Chen et al., 1972). The disease is characterised by extensive chlorosis, proliferation of axillary shoots, bushy growing habit, small leaves, shortened stolons and rhizomes, stunting and death of the plants (Marcone et al., 1997). Therefore it is important to select resistant genotypes to the above-mentioned phytoplasma.

The purpose of this study, conducted in a coastal area of the Basilicata region (Southern Italy), was to evaluate the agronomic behaviour of the 24 collected native populations of $C$. dactylon from Central and Southern Italy in order to identify biotypes with good qualities for turf use in the Mediterranean region.

\section{Materials and methods}

\section{Collection sites}

Samples of 24 of $C$. dactylon ecotypes were collected in different coastal and sub littoral sites of southern Italy characterised by Mediterranean climate with mild winters and hot summers. The mean annual temperatures of the collection sites ranged from 14 to $18^{\circ} \mathrm{C}$ with annual rainfall of less than $600 \mathrm{~mm}$ received predominantly in autumn and winter (Biondi et al., 1995). Altitude of the collection sites ranged from 0 to $400 \mathrm{~m}$ above sea level (asl). Plants from two habitat types, sandy dunes and hilly lawns, were selected for the trials. Every recorded specimen of interest was sampled from each location following the approach suggested by Romani et al. (2002), by walking on a transect. Whole plants (including roots embedded in soil) at the vegetative stage were collected every $2-5 \mathrm{~m}$ along the transect.

\section{Research site and experimental design}

Plant samples were vegetatively propagated by transplanting stolon

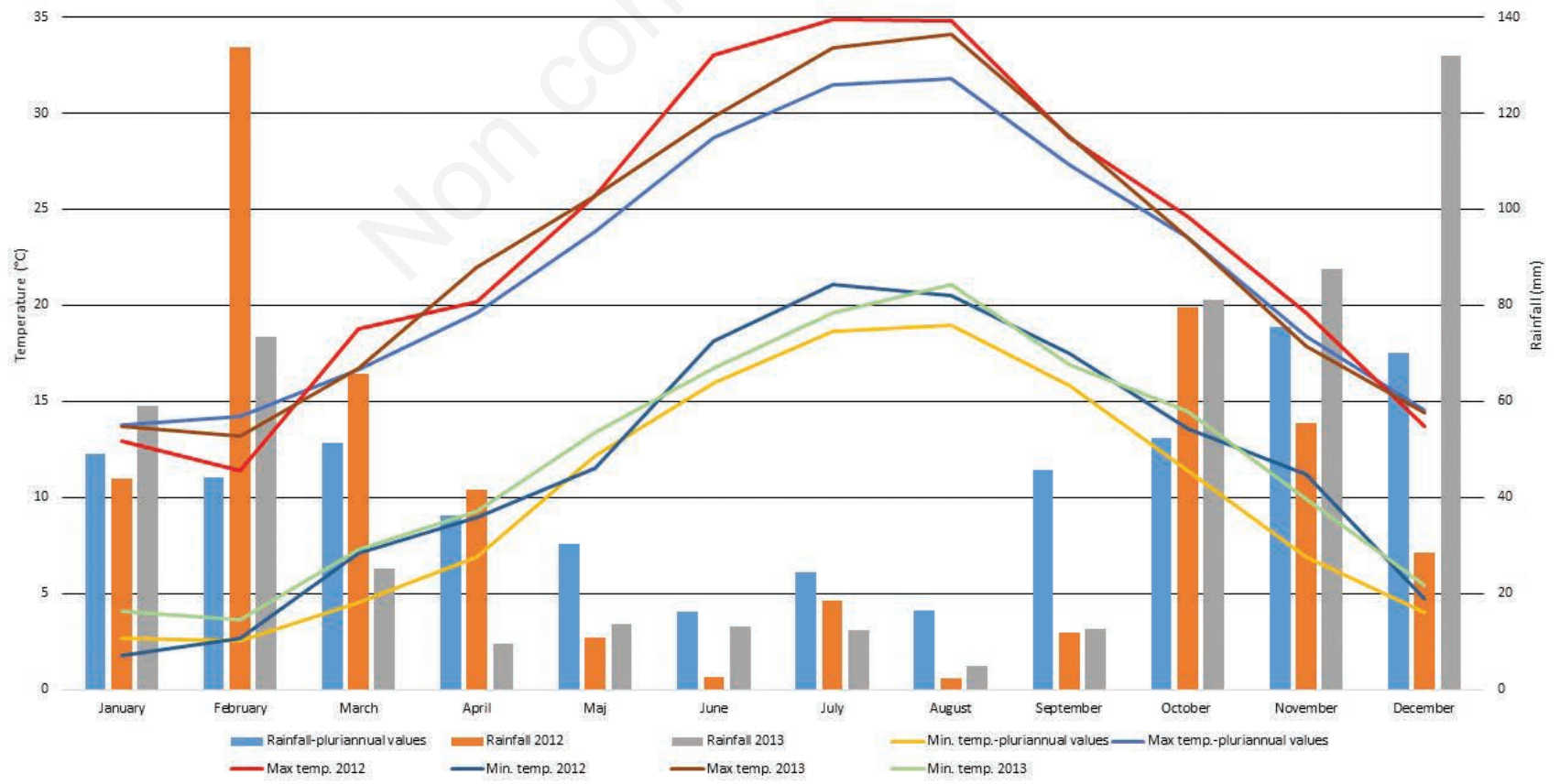

Figure 1. Trend of monthly minimum and maximum temperatures and rainfall recorded during the two-year of research in comparison to pluriannual values. 
fragments into plastic pots in an unheated greenhouse. When vegetative material was enough, plots were established in open field at Lucana Prati sod farm $\left(+40^{\circ} 22^{\prime} \mathrm{N},+16^{\circ} 47^{\prime} \mathrm{E} ; 6 \mathrm{~m}\right.$ asl) of Metaponto (Basilicata region, South of Italy).

The soil of the experimental area was clay-textured (64\% clay, $17 \%$ silt and 19\% sand), with good total nitrogen (1.1\%), available phosphorus (25 ppm) and rich in exchangeable potassium (350 ppm). Twentyfour autochthonous bermudagrasses and three bermudagrass commercial cultivars (Panama, Transcontinental and Yukon) used as standard reference, were compared in a randomised complete block design with 3 replications. Plot surface area was $2.25 \mathrm{~m}^{2}(1.5 \times 1.5 \mathrm{~m})$.

\section{Agronomic traits}

Between the first and the second year (December 2012-March 2013), the colour loss interval was determined by calculating the duration (d) of vegetative stasis on the basis of colour and ground cover of each turf plot: more precisely winter loss colour and spring green up were evalu- ated by visual judgment when the green cover of the plot was $\leq 20 \%$ and $\geq 80 \%$ respectively.

During the second year, from May to September 2013, the following data were recorded: i) growth rate, measured by a turfmeter as the turf weekly vertical growth of turfs maintained at $45 \mathrm{~mm}$ cutting height by a rotary mower; ii) colour index: it represents the intensity of the green colour and it is influenced by genetic characteristics of the species, conditions of environmental stress (water and/or thermal stress), from nutritional deficiencies and parasitic attacks. This parameter has been measured monthly using a Turf 500 NDVI-Turf Color Meter (Spectrum Technology, Aurora, C0, USA) that measures the reflected light in the spectral bands of red $(600 \mathrm{~nm})$ and infrared $(850 \mathrm{~nm})$, which correlate with the concentration of chlorophyll pigments in the leaves. From the measurement of NDVI, a colour index on a scale from 1 (=brown) to 9 (=dark green) can be calculated; iii) turf quality is a synthetic index evaluated by visual observations, and it highlights the quality of turf; it is influenced by the uniformity, density, turf colour, leaf texture, per-

Table 1. Origin of $C$. dactylon ecotypes collected in Central and Southern Italy, monthly and cumulative growth of ecotypes compared to commercial cultivars during the trial period (2013).

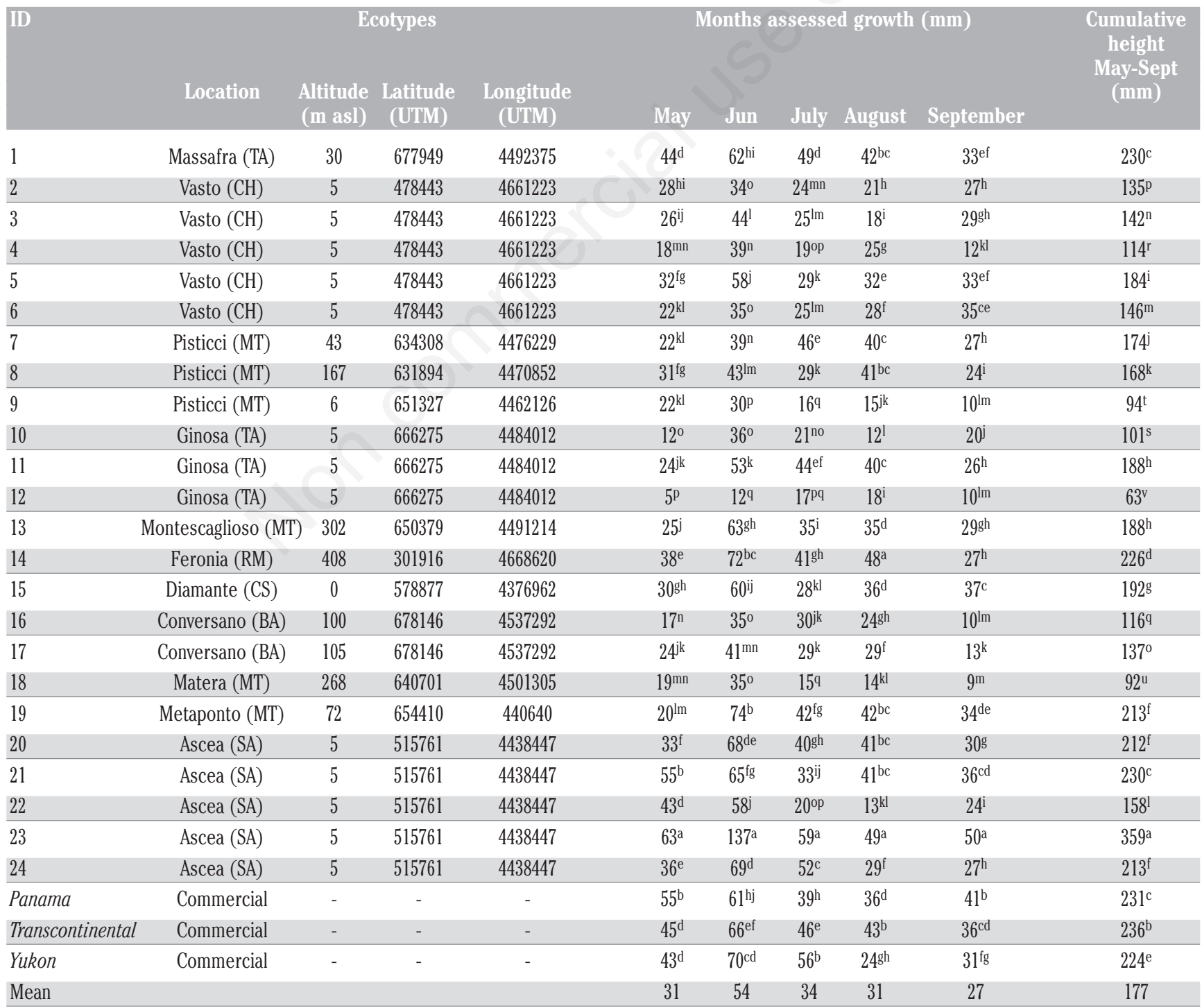

Values not having any letter in common are significantly different at $\mathrm{P} \leq 0.05$ (Duncan's test). 
centage of coverage and freedom from weeds, insects and disease damage. It varies from 1 (poorest quality) to 9 (highest quality - ideal turf); iv) ground cover percentage, is an assessment of the ground cover of the plot; this index was evaluated monthly by visual estimation.

All data were analysed with ANOVA procedure and means were compared with Duncan's test.

\section{Cultural practices}

Two fertilisations (May and July) with Nitrophoska gold (15-9-15), both with a rate of $60 \mathrm{~kg} \mathrm{ha}^{-1} \mathrm{~N}, 36 \mathrm{~kg} \mathrm{ha}^{-1} \mathrm{P}_{2} \mathrm{O}_{5}$ and $60 \mathrm{~kg} \mathrm{ha}^{-1} \mathrm{~K}_{2} \mathrm{O}$ were carried out; weekly irrigation to restore $60 \%$ of ETo and a weekly cutting frequency by a rotary mower with a mowing height of $45 \mathrm{~mm}$ were performed.

\section{Climate parameters}

As shown in Figure 1, the climatic trend was typically Mediterranean with an average temperature that was consistently higher than $15^{\circ} \mathrm{C}$ from April to October of 2012 and 2013.
During summer of 2012, maximum temperatures detected have constantly been around $35^{\circ} \mathrm{C}$. Monthly average minimum temperatures were lower than the average in January $\left(1.8^{\circ} \mathrm{C}\right)$ and higher than the average during October and November $\left(13.6\right.$ and $\left.11.2^{\circ} \mathrm{C}\right)$. During the first decade of December, a rough decrement of temperatures occurred determining the beginning of dormancy of accessions.

The average rainfall in 2012 was in line with pluriannual average values. Rains were concentrated in February (134 mm), March (66 $\mathrm{mm})$ and October $(80 \mathrm{~mm})$. During the summer period, the only relevant rainy event occurred in July (19 mm). The hottest months in 2013 were July and August with monthly average maximum temperatures of 33.4 and $34.1^{\circ} \mathrm{C}$. In the same period the absolute maximum temperature in many cases were close to $40^{\circ} \mathrm{C}$. The coldest months were January and February, respectively, with monthly average minimum temperatures of $4.1^{\circ} \mathrm{C}$ and $3.6^{\circ} \mathrm{C}$. In the summer period of 2013 , rainfall totals were scarce $(43 \mathrm{~mm})$; during the months of June, July and September, the rainfall amounted to a value slightly greater than 10 $\mathrm{mm}$, while in August, was only $5 \mathrm{~mm}$.

Table 2. Colour index and days of winter colour loss interval of ecotypes and commercial cultivars during the trial period (2012-2013).

\begin{tabular}{|c|c|c|c|c|c|c|c|}
\hline Ecotypes and cultivars & May & Jun & July & August & September & $\begin{array}{c}\text { Mean } \\
\text { May-Sept (2013) }\end{array}$ & $\begin{array}{l}\text { Winter colour loss interval } \\
\text { (d) }\end{array}$ \\
\hline 1 & $6.8^{\mathrm{bd}}$ & $6.7^{\mathrm{ab}}$ & $6.8^{\mathrm{a}}$ & $6.0^{\mathrm{ce}}$ & $6.0^{\mathrm{de}}$ & $6.5^{\mathrm{ab}}$ & $133^{\mathrm{j}}$ \\
\hline 2 & $6.5^{\mathrm{d}}$ & $6.2^{\mathrm{ef}}$ & $6.3^{\text {be }}$ & $6.1^{\mathrm{bd}}$ & $6.0^{\mathrm{de}}$ & $6.2^{\mathrm{ce}}$ & $146^{\mathrm{f}}$ \\
\hline 3 & $7.0^{\mathrm{ab}}$ & $6.6^{\mathrm{ac}}$ & $6.4^{\mathrm{bd}}$ & $6.2^{\mathrm{ac}}$ & $6.1^{\mathrm{cd}}$ & $6.5^{\mathrm{ab}}$ & $125^{\mathrm{k}}$ \\
\hline 4 & $7.0^{\mathrm{ab}}$ & $6.7^{\mathrm{ab}}$ & $6.3^{\text {be }}$ & $5.5^{\mathrm{hj}}$ & $5.4^{\mathrm{i}}$ & $6.2^{\mathrm{ce}}$ & $146^{\mathrm{f}}$ \\
\hline 5 & $6.7^{\mathrm{cd}}$ & $6.3^{\mathrm{cf}}$ & $5.9^{\mathrm{fg}}$ & $6.0^{\mathrm{ce}}$ & $5.8^{\mathrm{fg}}$ & $6.1^{\mathrm{df}}$ & $151^{\mathrm{e}}$ \\
\hline 6 & $6.7^{\mathrm{cd}}$ & $6.3^{\mathrm{cf}}$ & $6.1^{\text {ef }}$ & $6.3^{\mathrm{ab}}$ & $6.3^{\mathrm{ab}}$ & $6.3^{\mathrm{bd}}$ & $146^{\mathrm{f}}$ \\
\hline 7 & $6.8^{\mathrm{bd}}$ & $6.2^{\mathrm{ef}}$ & $6.3^{\text {be }}$ & $6.1^{\mathrm{bd}}$ & $6.1^{\mathrm{cd}}$ & $6.3^{\mathrm{bd}}$ & $143^{g}$ \\
\hline 8 & $6.8^{\mathrm{bd}}$ & $6.6^{\mathrm{ad}}$ & $6.2^{\mathrm{de}}$ & $5.6^{\mathrm{gi}}$ & $5.7^{\mathrm{gh}}$ & $6.2^{\mathrm{ce}}$ & $151^{\mathrm{e}}$ \\
\hline 9 & $6.8^{\mathrm{bd}}$ & $6.1^{\mathrm{fg}}$ & $6.1^{\mathrm{ef}}$ & $5.8^{\mathrm{eg}}$ & $6.3^{\mathrm{ab}}$ & $6.2^{\mathrm{ce}}$ & $152^{\mathrm{de}}$ \\
\hline 10 & $6.7^{\mathrm{cd}}$ & $6.3^{\mathrm{cf}}$ & $6.5^{\mathrm{b}}$ & $6.0^{\mathrm{ce}}$ & $6.3^{\mathrm{ab}}$ & $6.4^{\mathrm{ac}}$ & $146^{\mathrm{f}}$ \\
\hline 11 & $6.8^{\mathrm{bd}}$ & $6.6^{\mathrm{ad}}$ & $6.4^{\text {bd }}$ & $6.1^{\mathrm{bd}}$ & $6.2^{\mathrm{bc}}$ & $6.4^{\mathrm{ac}}$ & $138^{i}$ \\
\hline 12 & $6.2^{\mathrm{e}}$ & $5.9^{g}$ & $5.6^{\mathrm{h}}$ & $5.7^{\mathrm{fh}}$ & $6.0^{\text {de }}$ & $5.9^{f}$ & $145^{\mathrm{fg}}$ \\
\hline 13 & $6.7^{\mathrm{cd}}$ & $6.3^{\mathrm{df}}$ & $6.2^{\text {ce }}$ & $6.1^{\text {bd }}$ & $6.1^{\mathrm{cd}}$ & $6.3^{\text {bd }}$ & $146^{\mathrm{f}}$ \\
\hline 14 & $6.8^{\text {bd }}$ & $6.7^{\mathrm{ab}}$ & $6.5^{\mathrm{b}}$ & $6.0^{\text {ce }}$ & $6.2^{\mathrm{bc}}$ & $6.4^{\mathrm{ac}}$ & $157^{c}$ \\
\hline 15 & $6.9^{\mathrm{ac}}$ & $6.5^{\mathrm{ad}}$ & $6.3^{\text {be }}$ & $6.4^{\mathrm{a}}$ & $6.2^{\mathrm{bc}}$ & $6.5^{\mathrm{ab}}$ & $138^{\mathrm{i}}$ \\
\hline 16 & $6.7^{\mathrm{cd}}$ & $6.2^{\mathrm{ef}}$ & $6.2^{\mathrm{ce}}$ & $5.3^{\mathrm{j}}$ & $5.5^{\mathrm{hi}}$ & $6.0^{\text {ef }}$ & $153^{\mathrm{d}}$ \\
\hline 17 & $7.0^{\mathrm{ab}}$ & $6.2^{\mathrm{ef}}$ & $6.2^{\mathrm{ce}}$ & $5.6^{\mathrm{gi}}$ & $5.3^{\mathrm{i}}$ & $6.0^{\mathrm{ef}}$ & $166^{\mathrm{b}}$ \\
\hline 18 & $6.8^{\text {bd }}$ & $6.4^{\text {be }}$ & $6.3^{\text {be }}$ & $5.6^{\mathrm{gi}}$ & $5.8^{\mathrm{eg}}$ & $6.2^{\mathrm{ce}}$ & $173^{\mathrm{a}}$ \\
\hline 19 & $6.7^{\mathrm{cd}}$ & $6.4^{\text {be }}$ & $6.2^{\mathrm{ce}}$ & $5.8^{\mathrm{eg}}$ & $5.5^{\mathrm{hi}}$ & $6.1^{\mathrm{df}}$ & $141^{\mathrm{h}}$ \\
\hline 20 & $6.9^{\mathrm{ac}}$ & $6.5^{\mathrm{ad}}$ & $6.5^{\mathrm{b}}$ & $5.9^{\mathrm{df}}$ & $6.2^{\mathrm{bc}}$ & $6.4^{\mathrm{ac}}$ & $133^{j}$ \\
\hline 21 & $6.8^{\text {bd }}$ & $6.3^{\mathrm{df}}$ & $6.3^{\text {be }}$ & $5.9 \mathrm{df}$ & $5.9^{\mathrm{ef}}$ & $6.2^{\mathrm{ce}}$ & $138^{i}$ \\
\hline 22 & $6.8^{\text {bd }}$ & $6.3^{\mathrm{df}}$ & $5.8^{\mathrm{gh}}$ & $5.6^{6 \mathrm{i}}$ & $5.9^{\mathrm{ef}}$ & $6.1^{\mathrm{df}}$ & $146^{\mathrm{f}}$ \\
\hline 23 & $7.1^{\mathrm{a}}$ & $6.5^{\text {ad }}$ & $5.7^{\mathrm{gh}}$ & $5.7^{\text {fh }}$ & $5.8^{\mathrm{eg}}$ & $6.2^{\mathrm{ce}}$ & $138^{\mathrm{i}}$ \\
\hline 24 & $6.8^{\text {bd }}$ & $6.3^{\mathrm{cf}}$ & $6.1^{\mathrm{ef}}$ & $5.4^{\mathrm{ij}}$ & $5.7^{\mathrm{fg}}$ & $6.1^{\mathrm{df}}$ & $143^{g}$ \\
\hline Panama & $7.0^{\mathrm{ab}}$ & $6.3^{\mathrm{cf}}$ & $6.5^{\mathrm{bc}}$ & $6.2^{\mathrm{ac}}$ & $5.7^{\mathrm{fg}}$ & $6.4^{\mathrm{ac}}$ & $133^{j}$ \\
\hline Transcontinental & $7.0^{\mathrm{ab}}$ & $6.8^{\mathrm{a}}$ & $6.5^{\mathrm{bc}}$ & $6.1^{\text {bd }}$ & $5.9^{\mathrm{ef}}$ & $6.5^{\mathrm{ab}}$ & $125^{\mathrm{k}}$ \\
\hline Yukon & $7.0^{\mathrm{ab}}$ & $6.8^{\mathrm{a}}$ & $6.5^{b c}$ & $6.3^{\mathrm{ab}}$ & $6.5^{\mathrm{a}}$ & $6.6^{\mathrm{a}}$ & $133^{j}$ \\
\hline Average & 6.8 & 6.4 & 6.3 & 5.9 & 5.9 & 6.3 & 144 \\
\hline
\end{tabular}

Values not having any letter in common are significantly different at $\mathrm{P} \leq 0.05$ (Duncan's test). 


\section{Results and discussion}

The results of the evaluations carried out in 2012 and 2013, of the 24 native ecotypes of $C$. dactylon compared with 3 commercial bermudagrasses cultivars are shown in Tables 1-4.

The ecotype caused significant difference in each of the tested parameters when subjected to analysis of variance. For simplicity, the results for each parameter have been analysed separately.

\section{Monthly growth}

The mean total growth during the period May-September was $177 \mathrm{~mm}$ (Table 1), with extreme variations observed between the ecotype 12 (63 $\mathrm{mm})$ and ecotype $23(359 \mathrm{~mm})$. A similar behaviour was also found by Marchione (2008) on 12 commercial varieties of bermudagrass.

The extreme variability observed among the accessions compared is due in part to the genotypic characteristics of each accession and in part to an attack of phytoplasma BGWL, which resulted in an arrest of the vegetation and the discolouration of the leaf blades especially for accessions no. $12,18,9,10$ and 16 .

A prostrate growth habit reducing values of the cumulative growth was observed for the accessions no. 2, 3, 4 and 17; on the contrary accessions that showed the greatest growth were the no. $23(359 \mathrm{~mm})$ and no. 21, 1 and 14, all with values ranging around $230 \mathrm{~mm}$.

\section{Colour index}

Data in Table 2 show for this character, mean values above sufficiency, between 6.3 and 6.8 in the first 3 months of observation (May-July 2013), on the contrary, the colour index was below the sufficiency (5.9) during August and September 2013. These results are in accord to other researchers who studied 40 accessions of native $C$. dactylon collected in Sicily (Southern Italy) in order to identify biotypes with good qualities for broad scale turf in the Mediterranean region (Leto et al., 2008). The lower colour index values observed during August and September was due mainly to high temperatures and low rainfall, which caused a drought stress in plants.

Table 3. Turf quality of ecotypes and commercial cultivars during the trial period (2013).

\begin{tabular}{|c|c|c|c|c|c|c|}
\hline Ecotypes and cultivars & May & Jun & July & August & September & $\begin{array}{c}\text { Mean } \\
\text { May-Sept (2013) }\end{array}$ \\
\hline 1 & $6.1^{\mathrm{cd}}$ & $6.2^{\mathrm{de}}$ & $6.0^{\mathrm{de}}$ & $5.4^{\mathrm{cd}}$ & $5.4^{\mathrm{c}}$ & $5.8^{\mathrm{d}}$ \\
\hline 2 & $4.9^{\mathrm{k}}$ & $4.8^{\mathrm{Im}}$ & $4.9^{k}$ & $4.8^{\mathrm{hi}}$ & $4.7^{\mathrm{gi}}$ & $4.8^{j}$ \\
\hline 3 & $7.2^{\mathrm{a}}$ & $7.3^{\mathrm{a}}$ & $6.7^{\mathrm{a}}$ & $6.2^{\mathrm{a}}$ & $6.0^{\mathrm{a}}$ & $6.7^{\mathrm{a}}$ \\
\hline 4 & $5.3^{\mathrm{hi}}$ & $5.4^{\mathrm{hi}}$ & $5 . \mathrm{j}^{\mathrm{j}}$ & $5.1^{\mathrm{fg}}$ & $5.0^{\mathrm{de}}$ & $5.2^{\mathrm{gh}}$ \\
\hline 5 & $5.1^{\text {ik }}$ & $4.6^{\mathrm{mn}}$ & $4.3^{\mathrm{m}}$ & $4.6^{\mathrm{jk}}$ & $4.7^{\mathrm{fi}}$ & $4.7^{\mathrm{j}}$ \\
\hline 6 & $5.4^{\mathrm{h}}$ & $5.3^{\mathrm{hj}}$ & $5.0^{\mathrm{k}}$ & $5.2^{\mathrm{ef}}$ & $4.9^{\mathrm{df}}$ & $5.2^{\mathrm{gh}}$ \\
\hline 7 & $4.9^{\mathrm{k}}$ & $5.2^{\mathrm{ij}}$ & $5.0^{\mathrm{k}}$ & $5.7^{\mathrm{b}}$ & $4.7^{\mathrm{fi}}$ & $5.1^{\text {hi }}$ \\
\hline 8 & $5.3^{\mathrm{hj}}$ & $5.1^{\mathrm{jk}}$ & $5.0^{\mathrm{k}}$ & $5.1^{\mathrm{fg}}$ & $5.0^{\mathrm{de}}$ & $5.1^{\text {hi }}$ \\
\hline 9 & $5.8^{\mathrm{f}}$ & $4.9^{\mathrm{kl}}$ & $4.2^{\mathrm{m}}$ & $4.4^{\mathrm{kl}}$ & $4.5^{\mathrm{ij}}$ & $4.8^{\mathrm{j}}$ \\
\hline 10 & $6.1^{\mathrm{cd}}$ & $5.8^{\mathrm{g}}$ & $5.6^{\mathrm{h}}$ & $5.0^{\text {gh }}$ & $5.0^{\mathrm{de}}$ & $5.5^{\mathrm{ef}}$ \\
\hline 11 & $6.0^{\mathrm{ce}}$ & $5.9^{\mathrm{fg}}$ & $5.0^{\mathrm{k}}$ & $5.6^{\mathrm{bc}}$ & $5.1^{\mathrm{d}}$ & $5.5^{\mathrm{ef}}$ \\
\hline 12 & $3.8^{\mathrm{m}}$ & $3.5^{0}$ & $2.9^{\mathrm{n}}$ & $3.0^{\mathrm{m}}$ & $3.3^{1}$ & $3.3^{1}$ \\
\hline 13 & $6.4^{b}$ & $6.2^{\mathrm{cd}}$ & $6.1^{\mathrm{cd}}$ & $6.0^{\mathrm{a}}$ & $5.6^{\mathrm{bc}}$ & $6.1^{\mathrm{c}}$ \\
\hline 14 & $6.1^{\mathrm{cd}}$ & $6.3^{\text {bd }}$ & $6.2^{\mathrm{c}}$ & $5.6^{\mathrm{bc}}$ & $5.5^{\mathrm{bc}}$ & $5.9^{\mathrm{d}}$ \\
\hline 15 & $5.8^{\mathrm{ef}}$ & $6.0^{e f}$ & $5.7^{\mathrm{g}}$ & $5.6^{\mathrm{bc}}$ & $5.7^{\mathrm{b}}$ & $5.8^{\mathrm{d}}$ \\
\hline 16 & $4.6^{1}$ & $4.5^{\mathrm{n}}$ & $4.2^{\mathrm{m}}$ & $4.3^{1}$ & $4.4^{j}$ & $4.4^{\mathrm{k}}$ \\
\hline 17 & $4.9^{k}$ & $4.9^{\mathrm{kl}}$ & $4.6^{1}$ & $4.7^{\mathrm{ij}}$ & $4.9^{\mathrm{dg}}$ & $4.8^{j}$ \\
\hline 18 & $5.0^{0 \mathrm{k}}$ & $5.2^{\mathrm{ij}}$ & $4.9^{k}$ & $4.8^{\mathrm{hi}}$ & $3.9^{\mathrm{k}}$ & $4.9 \mathrm{ij}$ \\
\hline 19 & $5.5^{\text {gh }}$ & $5.3^{\mathrm{hj}}$ & $5.3^{\mathrm{ij}}$ & $4.9^{\text {hi }}$ & $4.8^{\mathrm{eh}}$ & $5.1^{\text {hi }}$ \\
\hline 20 & $6.1^{\mathrm{cd}}$ & $6.1^{\mathrm{df}}$ & $5.9^{\mathrm{ef}}$ & $5.5^{\mathrm{cd}}$ & $5.4^{\mathrm{c}}$ & $5.8^{d}$ \\
\hline 21 & $5.7^{f g}$ & $5.8^{\mathrm{g}}$ & $5.8^{\mathrm{fg}}$ & $4.9^{\mathrm{hi}}$ & $5.0^{\text {de }}$ & $5.4^{\mathrm{fg}}$ \\
\hline 22 & $5.3^{\mathrm{hj}}$ & $4.9^{\mathrm{kl}}$ & $4.8^{k}$ & $4.4^{1}$ & $4.4^{j}$ & $4.8^{j}$ \\
\hline 23 & $5.3^{\mathrm{hj}}$ & $5.4^{\mathrm{hi}}$ & $5.3^{\mathrm{ij}}$ & $4.9^{\text {hi }}$ & $4.9^{\mathrm{df}}$ & $5.2^{\mathrm{gh}}$ \\
\hline 24 & $5.8^{\mathrm{df}}$ & $5.5^{\mathrm{h}}$ & $5.5^{\mathrm{hi}}$ & $5.3^{\mathrm{de}}$ & $4.6^{\mathrm{hi}}$ & $5.4^{\mathrm{fg}}$ \\
\hline Panama & $6.1^{\mathrm{cd}}$ & $5.9^{f g}$ & $5.4^{\mathrm{ij}}$ & $5.6^{\mathrm{bc}}$ & $5.5^{\mathrm{bc}}$ & $5.7^{\mathrm{de}}$ \\
\hline Transcontinental & $6.3^{\mathrm{bc}}$ & $6.1^{\mathrm{df}}$ & $5.8^{\mathrm{fg}}$ & $5.5^{\mathrm{cd}}$ & $5.4^{\mathrm{c}}$ & $5.8^{d}$ \\
\hline Yukon & $6.5^{b}$ & $6.4^{\mathrm{bc}}$ & $6.4^{\mathrm{b}}$ & $6.2^{\mathrm{a}}$ & $6.0^{\mathrm{a}}$ & $6.3^{\mathrm{b}}$ \\
\hline Mean & 5.6 & 5.5 & 5.2 & 5.1 & 5.0 & 5.3 \\
\hline
\end{tabular}

Values not having any letter in common are significantly different at $\mathrm{P} \leq 0.05$ (Duncan's test). 
From May to September 2013, the ecotypes 1, 3 and 15 showed the highest mean value equal to 6.5 , whilst commercial cultivars gave mean values equal to 6.5 . In contrast accessions that showed the lowest value, equal to 6 , were accessions 12,16 and 17 .

\section{Colour loss interval}

The average duration of the dormancy period of compared accessions was 144 days. For most of the evaluated ecotypes (Table 2) it occurred between the first and second week of December, while the vegetative growth with the relative recovery of the colour was observed between the second week of April and the first week of May. Ecotypes that shown the lowest dormancy period were 3,1 and 20 , with values ranging between 125 and 133 days. On the contrary, accessions 18 and 17 showed the longest dormancy period among the ecotypes evaluated, with 173 and 166 days respectively. The three commercial varieties included in the research showed a period of dormancy ranging within 125 and 133 days, similar to the values achieved by best ecotypes.

\section{Turf quality}

Analysing data in Table 3 it is possible to verify that turf quality ranged between 5.6 (May) and 5 (September) (Table 3). This data are remarked in other native $C$. dactylon ecotypes of the Mediterranean region (Leto et al., 2008).

During the entire period of experimentation, ecotypes that showed the highest mean values were 3,13 and 14 , respectively, with 6.7 to 6.1 and 5.9; they also showed a good preservation of quality from May 2013 to September 2013. Among the commercial cultivars used in the experiment, the most satisfactory result was detected for Yukon, with a value equal to 6.3 , and a good stability during the entire period.

At the lowest level were ranked, accessions 12 and 16 , with values respectively equal to 3.3 and 4.4. These values extremely low were due partly to the genotypic characteristics of accession and to a considerable extent of phytoplasma BGWL attacks, which have widely affected the aesthetic quality of ecotypes. The lower values of these ecotypes have strongly influenced the mean of turf quality during whole period and also for single months.

\section{Ground cover percentage}

The coverage percentage (Table 4) showed a mean value generally equal to 70\%, in accordance with the findings of Volterrani et al. (1997) and Croce et al. (2001) in other Italian sites. Mean values higher than $75 \%$ were observed during the May-June period; during the AugustSeptember period, however, a decrease of the index has been noted,

Table 4. Ground cover percentage of ecotypes and commercial cultivars during the trial period (2013).

\begin{tabular}{|c|c|c|c|c|c|c|}
\hline Ecotypes and cultivars & May & Jun & July & August & September & $\begin{array}{c}\text { Mean } \\
\text { May-Sept (2013) }\end{array}$ \\
\hline 1 & $6.1^{\mathrm{cd}}$ & $6.2^{\mathrm{de}}$ & $6.0^{\mathrm{de}}$ & $5.4^{\mathrm{cd}}$ & $5.4^{c}$ & $5.8^{\mathrm{d}}$ \\
\hline 2 & $4.9^{\mathrm{k}}$ & $4.8^{\mathrm{Im}}$ & $4.9^{k}$ & $4.8^{\mathrm{hi}}$ & $4.7^{\mathrm{gi}}$ & $4.8^{j}$ \\
\hline 3 & $7.2^{\mathrm{a}}$ & $7.3^{\mathrm{a}}$ & $6.7^{\mathrm{a}}$ & $6.2^{\mathrm{a}}$ & $6.0^{\mathrm{a}}$ & $6.7^{\mathrm{a}}$ \\
\hline 4 & $5.3^{\mathrm{hi}}$ & $5.4^{\mathrm{hi}}$ & $5.3^{\mathrm{j}}$ & $5.1^{\mathrm{fg}}$ & $5.0^{\mathrm{de}}$ & $5.2^{\mathrm{gh}}$ \\
\hline 5 & $5.1^{\mathrm{ik}}$ & $4.6^{\mathrm{mn}}$ & $4.3^{\mathrm{m}}$ & $4.6^{\mathrm{jk}}$ & $4.7^{\mathrm{fi}}$ & $4.7^{\mathrm{j}}$ \\
\hline 6 & $5.4^{\mathrm{h}}$ & $5.3^{\mathrm{hj}}$ & $5.0^{\mathrm{k}}$ & $5.2^{\mathrm{ef}}$ & $4.9 \mathrm{df}$ & $5.2^{\mathrm{gh}}$ \\
\hline 7 & $4.9^{\mathrm{k}}$ & $5.2^{\mathrm{ij}}$ & $5.0^{\mathrm{k}}$ & $5.7^{\mathrm{b}}$ & $4.7^{\mathrm{fi}}$ & $5.1^{\mathrm{hi}}$ \\
\hline 8 & $5.3^{\mathrm{hj}}$ & $5.1^{\mathrm{jk}}$ & $5.0^{\mathrm{k}}$ & $5.1^{\mathrm{fg}}$ & $5.0^{\mathrm{de}}$ & $5.1^{\mathrm{hi}}$ \\
\hline 9 & $5.8^{f}$ & $4.9^{\mathrm{kl}}$ & $4.2^{\mathrm{m}}$ & $4.4^{\mathrm{kl}}$ & $4.5^{\mathrm{ij}}$ & $4.8^{j}$ \\
\hline 10 & $6.1^{\mathrm{cd}}$ & $5.8^{g}$ & $5.6^{\mathrm{h}}$ & $5.0^{\mathrm{gh}}$ & $5.0^{\mathrm{de}}$ & $5.5^{\mathrm{ef}}$ \\
\hline 11 & $6.0^{\mathrm{ce}}$ & $5.9 \mathrm{fg}$ & $5.0^{\mathrm{k}}$ & $5.6^{\mathrm{bc}}$ & $5.1^{\mathrm{d}}$ & $5.5^{\mathrm{ef}}$ \\
\hline 12 & $3.8^{\mathrm{m}}$ & $3.5^{\circ}$ & $2.9^{\mathrm{n}}$ & $3.0^{\mathrm{m}}$ & $3.3^{1}$ & $3.3^{1}$ \\
\hline 13 & $6.4^{b}$ & $6.2^{\mathrm{cd}}$ & $6.1^{\mathrm{cd}}$ & $6.0^{\mathrm{a}}$ & $5.6^{\mathrm{bc}}$ & $6.1^{\mathrm{c}}$ \\
\hline 14 & $6.1^{\mathrm{cd}}$ & $6.3^{\text {bd }}$ & $6.2^{\mathrm{c}}$ & $5.6^{\mathrm{bc}}$ & $5.5^{\mathrm{bc}}$ & $5.9^{\mathrm{d}}$ \\
\hline 15 & $5.8^{\mathrm{ef}}$ & $6.0^{\mathrm{ef}}$ & $5.7^{\mathrm{g}}$ & $5.6^{\mathrm{bc}}$ & $5.7^{\mathrm{b}}$ & $5.8^{\mathrm{d}}$ \\
\hline 16 & $4.6^{1}$ & $4.5^{\mathrm{n}}$ & $4.2^{\mathrm{m}}$ & $4.3^{1}$ & $4.4^{j}$ & $4.4^{\mathrm{k}}$ \\
\hline 17 & $4.9^{\mathrm{k}}$ & $4.9^{\mathrm{kl}}$ & $4.6^{1}$ & $4.7^{\mathrm{ij}}$ & $4.9 \mathrm{dg}$ & $4.8^{j}$ \\
\hline 18 & $5.0^{0 \mathrm{k}}$ & $5.2^{\mathrm{ij}}$ & $4.9^{\mathrm{k}}$ & $4.8^{\mathrm{hi}}$ & $3.9^{\mathrm{k}}$ & $4.9^{\mathrm{ij}}$ \\
\hline 19 & $5.5^{\mathrm{gh}}$ & $5.3^{\mathrm{hj}}$ & $5.3^{\mathrm{ij}}$ & $4.9^{\mathrm{hi}}$ & $4.8^{\mathrm{eh}}$ & $5.1^{\mathrm{hi}}$ \\
\hline 20 & $6.1^{\mathrm{cd}}$ & $6.1^{\mathrm{df}}$ & $5.9^{\mathrm{ef}}$ & $5.5^{\mathrm{cd}}$ & $5.4^{\mathrm{c}}$ & $5.8^{\mathrm{d}}$ \\
\hline 21 & $5.7^{\mathrm{fg}}$ & $5.8^{g}$ & $5.8^{\mathrm{fg}}$ & $4.9^{\mathrm{hi}}$ & $5.0^{\mathrm{de}}$ & $5.4^{\mathrm{fg}}$ \\
\hline 22 & $5.3^{\mathrm{hj}}$ & $4.9^{\mathrm{kl}}$ & $4.8^{\mathrm{k}}$ & $4.4^{1}$ & $4.4^{j}$ & $4.8^{j}$ \\
\hline 23 & $5.3^{\mathrm{hj}}$ & $5.4^{\mathrm{hi}}$ & $5.3^{\mathrm{ij}}$ & $4.9^{\mathrm{hi}}$ & $4.9^{\mathrm{df}}$ & $5.2^{\mathrm{gh}}$ \\
\hline 24 & $5.8^{\mathrm{df}}$ & $5.5^{\mathrm{h}}$ & $5.5^{\mathrm{hi}}$ & $5.3^{\mathrm{de}}$ & $4.6^{\mathrm{hi}}$ & $5.4^{\mathrm{fg}}$ \\
\hline Panama & $6.1^{\text {cd }}$ & $5.9^{\mathrm{fg}}$ & $5.4^{\mathrm{ij}}$ & $5.6^{\mathrm{bc}}$ & $5.5^{\mathrm{bc}}$ & $5.7^{\mathrm{de}}$ \\
\hline Transcontinental & $6.3^{\mathrm{bc}}$ & $6.1^{\mathrm{df}}$ & $5.8^{\mathrm{fg}}$ & $5.5^{\mathrm{cd}}$ & $5.4^{\mathrm{c}}$ & $5.8^{\mathrm{d}}$ \\
\hline Yukon & $6.5^{b}$ & $6.4^{\mathrm{bc}}$ & $6.4^{\mathrm{b}}$ & $6.2^{\mathrm{a}}$ & $6.0^{\mathrm{a}}$ & $6.3^{b}$ \\
\hline Mean & 5.6 & 5.5 & 5.2 & 5.1 & 5.0 & 5.3 \\
\hline
\end{tabular}

Values not having any letter in common are significantly different at $\mathrm{P} \leq 0.05$ (Duncan's test). 
with mean values varying from $57 \%$ to $63 \%$. Among the ecotypes compared, the one that showed the highest mean value was the ecotype 3 (87\%); satisfactory values were also reported for accessions 13 and 1 , with mean values equal to 84 and $77 \%$ respectively. Commercial cultivar that achieved the best value was Yukon with $85 \%$.

The lowest value was reached by genotype 12 (22\%). This anomalous value is partly imputable to the massive attack of BGWL, which continued during the entire period of the research.

\section{Conclusions}

The research project was of particular interest in increasing knowledge on bermudagrass germplasm in Central and Southern Italy.

The bio-agronomic evaluation of 24 ecotypes of Cynodon spp. showed high variability in the collected germplasm, as far as the biometric and qualitative parameters were concerned.

Many of the ecotypes compared resulted susceptible to BGWL, which influenced all the considered parameters with the exception of ecotypes $1,3,13,14,21,23$ and 24 . Susceptibility to phytoplasma is a factor to be considered for the selection of ecotypes for turf.

The native accession 3 from Vasto (Abruzzo region) achieved the best results among-native bermudagrasses and showed the same or higher values than Yukon, Panama and Transcontinental cultivars, used as reference of commercial varieties. For some parameters, several ecotypes (1, 13, 14 e 20) from Massafra (Puglia region, Southern Italy), Montescaglioso (Basilicata region, Southern Italy), Feronia (Lazio region, Central Italy) and Ascea (Campania region, Southern Italy) showed similar biometric and qualitative performances than Yukon, Panama e Transcontinental and could result of great interest for selecting future bermudagrass cultivars for turfgrasses use.

Further studies are needed to better characterise the above native accessions of $C$. dactylon, in order to promote them in the turfgrass market and to assess the potential benefits compared to alien species in the Mediterranean environments.

\section{References}

Anderson JA, Taliaferro CM, Wu YQ, 2007. Freeze tolerance of seed- and vegetatively propagated bermudagrasses compared with standard cultivars. Appl. Turfgrass Sci. 4.

Anderson JM, Taliaferro CM, Martin D, 1993. Evaluating freeze tolerance of bermudagrass in a controlled environment. Hort. Sci. 28:955.

Beard JB, 1973. Warm season turfgrasses. In: J.B. Beard (ed.), Turfgrass: science and culture. Prentice Hall-Inc., Englewood Cliffs, NJ, pp 133-165.

Biondi B, Baldoni M, 1995. The climate and vegetation of peninsular Italy. Coll. Phytosoc. 23:675-721.

Cereti CF, Rossini F, Nassetti F, 2004. Water supply reduction on warm season grasses in Mediterranean environment. Acta Hort. 661:153-8.

Chapman GP, 1996. The biology of grasses. Wallingford, Oxon, UK, pp 304.

Chen TC, Lee CS, Chen MJ, 1972. Mycoplasmalike organisms in Cynodon dactylonand Brachiaria distachya affected by white leaf disease. Rep. Taiwan Sugar Exp. Stn. 56:49-55.

Croce P, De Luca A, Mocioni M, Volterrani M, Beard JB, 2001. Warmseason turfgrass species and cultivar characterizations for a Mediterranean climate. Int. Turfgrass Soc. Res. J. 9:855-9.

Davolio R, Ligabue M, Restani A, Ruozzi F, 2000. Tests varieties for turfing and turf. Inf. Agr. 39:51-7. de Bruijn K, 2010. Warm-season grasses for the Mediterranean area.pp 245-249 in Proc. II European Turfgrass Soc. Conf., Angers, France.

De Luca A, Volterrani M, Gaetani M, Grossi N, Croce P, Mocioni M, Lulli F, Magni S, 2008. Warm-season turfgrass adaptation in northern Italy. Proc. 1st European Turfgrass Society Conference, Pisa, Italy. Stamperia Editoriale Pisana, Pisa, Italy, pp 75-76.

Erdogan R, Zaimoglu Z, Mansuroglu S, 2011. Utilization of leachate for irrigation in landfill cover soil remediation projects. J. Food Agric. Environ. 9:979-82.

Esmaili S, Salehi H, 2012. Effects of temperature and photoperiod on postponing bermudagrass (Cynodon dactylon [L.] Pers.) turf dormancy. J. Plant Physiol. 169:851-8.

Harlan J, de Wet JMJ, 1969. Sources of variation in Cynodon dactylon [L.] Pers. Crop Sci. 9:774-8.

Huang B, 2008. Turfgrass water requirements and factors affecting water usage. In: J.B. Beard and M.P. Kenna (eds.), Water quality and quantity issues for turfgrass in urban landscapes. CAST Spec. Publ. No. 27. CAST, Ames, IA, pp 193-205.

Kenna MP, 2008. Turfgrass and the environment. In: Beard JB, Kenna MP (eds), Water quality and quantity issues for turfgrasses in urban landscapes. CAST Spec. Publ. 27. CAST, Ames, IA, pp 65-90.

Leto C, Sarno M, Tuttolomondo T, La Bella S, Licata M, 2008. Two years of studies into native bermudagrass (Cynodon spp.) germplasm from Sicily (Italy) for the constitution of turf cultivars. Acta Hort. 783:39-48.

Malcolm CV, Smith ST, 1971. Growing plants with salt water. J. Agric. Western Austr. 12:41-4.

Marchione V, 2004. Evaluation of growth rate and aesthetic parameters of several bermudagrass varieties in Southern Italy. Acta Hortic. 661:399-401.

Marchione V, 2008. Performance of several Cynodon dactylon and Zoysia japonica cultivars in Southern Italy. Proc. 1st European Turfgrass Society Conference, Pisa, Italy. Stamperia Editoriale Pisana, Pisa, Italy, pp 125-126.

Marchione V, 2012. Effect of different irrigation regimes on turf quality of warm season species in Mediterranean climate. Proc. $3^{\text {rd }}$ European Turfgrass Conference, Kristiansand, Norway. Bioforsk Fokus 8:48-50.

Marcone C, Ragozzino A, Seemüller E, 1997. Detection of Bermuda grass white leaf disease in Italy and characterization of the associated phytoplasma by RFLP analysis. Plant Dis 81:862-6.

McCoy EL, Kunkel P, Prettyman GW, McCoy KR, 2007. Root zone composition effects on putting green soil water. Online. Appl. Turfgrass Sci. 19:1-11.

McCoy EL, McCoy KR, 2005. Putting green root zone amendments and irrigation water conservation. USGA Turfgrass Environ. Res. Online 4:1-9.

Munshaw GC, Ervin EH, Shang C, Askew SD, Zhang X, Lemus RW, 2006. Influence of lateseason iron, nitrogen, and seaweed extract on fall color retention and cold tolerance of four bermudagrass cultivars. Crop Sci. 6:273-83.

Peacock CH, Lee DJ, Reynolds WC, Gregg JP, Cooper RJ, Bruneau AH, 2004. Effects of salinity on six Bermudagrass turf cultivars. Acta Hort. 661:193-7.

Potenza G, Castronuovo D, Fascetti S, Perniola M, Miccolis V, Lovelli S, Candido V, 2012. Turfgrasses: invasive alien species (IAS) as en emerging problem in Italy. pp 97-98 (Abstract) in 6th European Botanic Gardens Congress, Chios Island, Grecia, BGCI, UK.

Potenza G, Fascetti S, Castronuovo D, Lovelli S, Perniola M, Viggiani R, Rossi R, Marchione V, Candido V, 2014. Collection and preliminary characterisation of native turfgrass accessions of Cynodon dactylon L. in the Mediterranean area. J. Food Agric. Environ. 12:770-4. Romani M, Piano E, Carroni AM, Pecetti L, 2004. Evaluation of native 
bermudagrass (Cynodon dactylon) germplasm from Italy for the selection of adapted turfgrass cultivars. Acta Hort. 661:381-6.

Romani M, Piano E, Pecetti L, 2002. Collection and preliminary evaluation of native turfgrass accessions in Italy. Genet. Resour. Crop Evol. 49:341-8.

Severmutlu S, Mutlu N, Shearman RC, Gurbuz E, Gulsen 0, Hocagil M, Karaguzel 0, Heng-Moss T, Riordan TP, Gaussoin RE, 2011. Establishment and turf qualities of warm-season turfgrasses in the Mediterranean region. HorTechnol. 21:67-81.

Turgeon AJ, 2004. Turfgrass species. In: A.J. Turgeon (ed.), Turfgrass management. Pearson Prentice Hall Inc, Upper Saddle River, NJ, pp 59-119.

van Wijk AJP, 1993. Turfgrasses in Europe: cultivar evaluation and advances in breeding. pp 26-38 in Proc. 7th Int. Turfgrass Research Conference, Palm Beach, FL, USA.

Veronesi F, Falcinelli M, 1988. Evaluation of an Italian genetic variation and predicted gain from selection for winter germplasm collection of Festuca arundinacea through a multi-hardiness and turf quality in a perennial ryegrass top crossvariate analysis. Euphytica 38:211-220.

Veronesi F, Falcinelli M, Lucaroni B, Russi L, 1997. Scelte varietali in loietto inglese (Lolium perenne L.) e festuca arundinacea (Festuca arundinacea Schreb.) per il loro utilizzo nella conduzione di tappeti erbosi ad uso tecnico, sportivo e ricreativo in centro Italia. Riv.
Agron. 31:127-34.

Veronesi F, Falcinelli M, Panella A, 1991a. Le principali specie microterme utilizzabili nell'impianto di tappeti erbosi a uso tecnico, sportivo e ricreativo in Italia. I: Insediamento, densità e colore. Riv. Agron. 25:69-75.

Veronesi F, Falcinelli M, Panella A, 1991b. The main microtherm species used in the system of turf for technical purposes, sports and recreation in Italy: 1. Settlement, density and color. Fodder Crops Sect. Meeting. Brugge, Belgium, pp 107-109.

Veronesi F, Falcinelli M, Panella A, 1992. Le principali specie microterme utilizzabili nell'impianto di tappeti erbosi a uso tecnico, sportivo e ricreativo in Italia. II: Quantità di vegetazione asportata per taglio, larghezza della lamina fogliare e spessore del feltro. Riv. Agron. 26:104-10.

Volterrani M, Grossi N, Pardini G, Miele S, Gaetani M, Magni S, 1997. Warm season turfgrass adaptation in Italy. Int. Turfgrass Soc. Res. J. 8:1344-54.

Volterrani M, Pardini G, Grossi N, Gaetani M, Miele S, Pietrini E, 1996. Evaluation of the adaptability of grass macrotherm species from turfgrass to environmental conditions in central Italy. Italus Hortus $5: 10-6$. 